УДК 340.12

DOI https://doi.org/10.32844/2618-1258.2019.3-2.41

КУРОВСЬКА I.A.

\title{
ПРИНЦИП ВЕРХОВЕНСТВА ПРАВА В ПРАВОВІЙ СИСТЕМІ ЕС ТА МІЖНАРОДНОМУ ПРАВІ
}

\begin{abstract}
У статті досліджуються деякі доктринальні підходи щодо змісту та юридичної природи доктрини верховенства права в правовій системі ЄС. Доводиться, що доктрина верховенства залишається одним із принципів права Європейського Союзу. Так, вже протягом 50 років після того, як Суд справедливості ЄС визнав його у відомій справі Costa v ENEL, цей принцип залишається значною мірою некодифікованим і таким, що походить із судової практики. Відмічається, що не лише основоположні договори Євросоюзу, а й інші обов'язкові акти, що формують асquis $\mathrm{EC}$, мають першочергове значення у національному законодавстві. Таким чином, констатується, що сформульована доктрина верховенства права перетворилася на принцип, що гарантує ефективність права ЄС. Зроблено висновок, що в установчих договорах ЄС, зокрема Договорі про Європейський Союз (2007р.), верховенство права постає не стільки як принцип права, скільки як філософсько-соціальна категорія - загальнолюдська цінність, яку мають поважати і якої мають дотримуватися. Це підтверджується системним тлумаченням відповідних нормативних положень під кутом аксіологічного розуміння їх потенціалу. Зокрема, в Договорі про ЄС ці цінності знайшли своє відображення таким чином: а) у Преамбулі зазначено, що держави-члени заснували Європейський Союз, отримуючи натхнення від культурного, релігійного та гуманістичного спадку Свропи, з якого розвинулися загальні принципи (непорушності та невідчужуваності прав особистості, свободи, демократії, рівності та верховенства права); б) у ст. $2 \epsilon$ перелік цінностей, на яких було засновано Союз, тут також підкреслюється, що ці цінності є спільними для всіх держав-членів, а також закріплено телеологічні домінанти, що демонструють практичне застосування наведених цінностей у суспільстві - панування плюралізму, недискримінації, толерантності, правосуддя, солідарності та рівності чоловіків та жінок. Отже, саме у такий спосіб установчі договори ЄС нормативно закріпили загальновизнані принципи права, до яких належить і принцип верховенства права, як засадничі, основоположні щодо правової системи Європейського Союзу, відповідно, і правових систем його держав-членів.
\end{abstract}

Ключові слова: Свропейський Союз, принципи права, верховенство, пряма дія, Суд ЄС, інтеграчія в європейський правовий простір.

The author explores in the article some doctrinal approaches to the essence and legal nature of the rule of law doctrine in the EU legal system. She proves that the rule of law remains one of the key principles of the European Union law. Thus, 50 years after the EU Court of Justice recognized it in the well-known Costa v ENEL case, this principle remains mostly uncodified and such that derived from the case law. It is noted in the article that not only the fundamental treaties of the European Union, but also other binding acts that form the EU Acquis have priority over national legislation. Thus, it is stated that the formulated rule of law doctrine has become a principle that guarantees the effectiveness of EU law. It is concluded that in the founding treaties of the EU, in particular the Treaty on European Union (2007), the rule of law appears not so much as a principle of law, but as a philosophical and social category - a universal human value that must be respected and respected. This is confirmed by the systematic interpretation of the relevant regulations at an angle of axiological understanding of their potential. In particular, in the EU Treaty, these values were reflected: a) the Preamble states that the

(C) КУРОВСЬКА І.А. - кандидат юридичних наук, старший науковий співробітник, завідувач відділу теорії та практики законотворчої діяльності (Інститут законодавства Верховної Ради України) 
Member States established the European Union, drawing inspiration from the cultural, religious and humanistic heritage of Europe, from which developed common values (inviolability and inalienability of individual rights, freedom, democracy, equality and the rule of law); b) in Art. 2 contains a list of the values on which the Union was founded, it also emphasizes that these values are common to all Member States; and teleological dominants are enshrined to demonstrate the practical application of these values in society - the dominance of pluralism, non-discrimination, tolerance, justice, solidarity and equality between men and women. Thus, it is in this way that the founding treaties of the EU have legally enshrined the generally recognized principles of law, which include the rule of law, as fundamental, fundamental to the legal system of the European Union, and accordingly the legal systems of its Member States.

Key words: European Union, principles of law, rule of law, direct action, EU Court of Justice, integration into the European legal area.

Вступ. Сучасна юридична наука визнає принцип верховенства права насамперед як один iз найважливіших принципів існування та функціонування сучасних національних і міжнародної правових систем.

Як відомо, євроінтеграційні прагнення України мають на меті не лише набуття повноправного членства в $Є С$, але й реальне прийняття нашою державою європейських демократичних цінностей та насамперед трансформацію країни у демократичну та правову державу. Останнє можливе тільки на основі перебудови національної правової системи відповідно до європейської за умови дотримання загальновизнаного фундаментального принципу - принципу «верховенства права».

Реалізація визначеного Законом України «Про засади внутрішньої і зовнішньої політики України» [12] курсу на європейську інтеграцію, активна участь нашої держави у роботі міжнародних міжурядових організацій регіонального характеру тісно пов'язані із імплементацією європейських правових стандартів до українського законодавства. У ході реформування вітчизняної правової системи відповідно до європейських стандартів іноді запозичуються навіть цілі інститути, раніше не відомі українській системі державотворення. Водночас усі запозичення такого роду розпочинаються з імплементації демократичних стандартів, які на принциповому рівні окреслюють основні риси та особливу природу європейського типу держави і права, зрештою, цінності людської цивілізації отримують втілення у пануванні верховенства права, демократичному правлінні, повазі до прав людини тощо.

Безумовно, Україна може застосовувати ті стандарти, які вважає найефективнішими для розвитку та удосконалення власної правової системи, досягнення нею відповідного рівня розвитку. Проте наш вибір має грунтуватися на досвіді держав, які здійснили правові реформи та стали членами $\mathrm{CC}$, забезпечивши громадянам вищий рівень життя, а також враховувати міжнародні зобов'язання України.

У цьому зв’язку актуальності набувають дослідження місця та ролі принципу верховенства права в правовій системі ЄС.

Аналіз останніх публікацій та досліджень. Верховенству права як одному з проявів справедливості та розумності приділяється велика увага на доктринальному рівні науковцями, серед яких можемо виділити праці М.О. Баймуратова, Ю.О. Волошина, В.М. Гайворонського, В.С. Журавського, А.П. Зайця, О.Л. Копиленко, В.Ф.Погорілка, П.М. Рабіновича, А.О. Селіванова, В.Ф. Сіренка, О.Ф. Скакун, Ю.М. Тодики, Ю.С. Шемшученка та інших. Дослідженню змістових характеристик верховенства права приділяли свою увагу С.П. Головатий, М.І. Козюбра, Л.Г. Паращук, М.Г. Патей-Братасюк, С.В. Шевчук та інші.

Постановка завдання. Метою статті $€$ - визначити місце та роль принципу верховенства права в системі права ЄС.

Результати дослідження. У юридичній та філософській літературі усталеною є думка про те, що основоположні принципи права, до яких належить і принцип верховенства права є засобом зв'язку як з природним і соціальним світом, так і з чинними філософсько-соціологічними парадигмами знань. 3 одного боку, вони пов'язані із загальнонауковими методами досліджень, а 3 іншого - є основою самооновлення, самоорганізації, посилення впорядкованості та організованості системи права, а також фундаментом розробки інших, похідних принципів та водночас засадничою підвалиною формування єдиної системи законодавства $[11$, с. 48,51$]$. 
Закріплення принципу верховенства права на національному рівні в конституціях, конституційних актах практично всіх держав світу, а також на міжнародному рівні в міжнародно-правових актах (угодах, конвенціях, хартіях, статутах тощо), свідчить про те, що цей принцип став гарантом спроможності до творення демократичної, соціальної, правової держави та громадянського суспільства, а на міжнародному рівні - основою співіснування і співпраці між різними народами й культурами.

Отже, з системного аналізу вищенаведеного випливає фактична взаємодія міжнародного права $з$ правом європейським, яке формується в результаті активних інтеграційних процесів, що здійснюються на континенті, завдяки діяльності доволі крупних міжнародних міждержавних об’єднань інтеграційного характеру, насамперед Європейського Союзу.

Дійсно, характеризуючи європейське право як сукупність правових норм, що регулюють взаємовідносини, що складаються в рамках європейських інтеграційних об'єднань [1, с. 5-6], представники доктрини тлумачать його як в широкому [6], так і в вузькому розумінні $[14$, с. 5$]$.

В контексті дослідження, що проводиться, інтерес представляє, по-перше, саме розуміння європейського права як права $\mathcal{C}$, , а, по-друге, його співвідношення саме з міжнародним публічним правом, в якому діє концепція - концепт - принцип верховенства права, - це детерміноване тим, що саме тут має місце низка методологічних особливостей, що $є$ важливими з теоретико-аксіологічних позицій, та на яких варто зупинитись.

Перша методологічна особливість європейського права, як права $\mathrm{CC}$, міститься у складності визначення місця європейського права в системі міжнародного права, враховуючи на унікальність ЄС як складного інтеграційного об’єкта міжнародних відносин. Тобто, з одного боку, виходячи 3 того, що під міжнародним правом прийнято розуміти особливу правову систему, що регулює міжнародні відносини і виражає узгоджену волю держав [2, с. 14], європейське право можна однозначно визначати як частину системи загального міжнародного права, що $є$ ускладненою регіональною специфікою. 3 іншого боку, право ЄС є унікальним за своєю структурою, загальними принципами і джерелами, отже, тому воно являє собою самостійну системно-нормативну одиницю, яка хоча і не суперечить міжнародному праву, все ж помітно від нього відрізняється. Навіть більше, виходячи з архітектоніки права ЄС, до якого входить й національне право держав-членів, його можна сприймати як право внутрішнє щодо самої Організації, а також до їі держав-членів, а сам Європейський Союз прирівнювати до держави як суб'єкта на міжнародній арені.

Другою методологічною особливістю європейського права є те, що право ЄС суттєво відрізняється від міжнародного права, враховуючи основоположні параметральні ознаки останнього. На це слушно звертає увагу дослідниця П.І. Вершиніна [3]. Так, на ії думку, якби право ЄС дійсно було б частиною міжнародної системи, воно б включало загальних суб'єктів права і базувалося б на однакових принципах, джерелах і структурі міжнародного права. Ба більше, суб'єктами міжнародного публічного права є держави, нації і народи, що борються за самовизначення, державоподібні утворення і міжнародні організації. Суб'єктами ж права ЄС є держави - члени ЄC, інститути та органи ЄС, громадяни і юридичні особи ЄС, які мають офіційне місцезнаходження на території $€ \mathrm{C}$.

Таким чином, якщо в міжнародному праві принципи поділяються на основні та галузеві, то в праві ЄС вони розділені на загальні та функціональні. Отже, в стратегічному аспекті вони не суперечать основним принципам міжнародного права, однак включають в себе унікальні положення. Деякі з загальних принципів мають пряме відношення до внутрішньої діяльності в ЄС (принцип пропорційності, який дозволяє Співтовариствам здійснювати свою юрисдикцію лише в межах їх повноважень; принцип субсидіарності, який визначає необхідність вирішення питань, що виникають, на місцях їх виникнення). Інші принципи гарантують справедливість і безпеку громадян на території ЄС (принцип охорони прав і свобод особистості, недискримінації, рівності чоловіків і жінок, захисту навколишнього середовища, захисту від недобросовісної конкуренції).

До функціональних принципів належать принцип верховенства права ЄС (пріоритет норм права ЄС над нормами внутрішньодержавного права) і принцип прямої дії права ЄС (дія норм права без додаткової імплементації в правову систему держави-учасниці). Необхідно наголосити на тому, що останній принцип не має аналогів в міжнародному праві.

Отже, можна зазначити, що в праві ЄС має місце своєрідне розуміння принципу верховенства права, що відрізняє його від загального розуміння цього принципу в рамках міжнародного права, а саме - цей принцип розуміється як принцип верховенства права ЄС, тобто: по-перше, він має більш звужений характер, що фактично змінює локалізацію його дії на територію самого 
ЄС та його держав-членів; по-друге, його змістовне наповнення обмежується явно функціонально-технологічним аспектом, а саме пріоритетом норм права СС над нормами внутрішньодержавного права, тобто правових систем держав - членів ЄС.

Зауважимо, що поява такого своєрідного розуміння принципу верховенства права, як верховенство права $\mathcal{C}$, насамперед пов'язана з ретроспективною діяльністю Суду справедливості Європейського Союзу (далі - Суд СС). Як відомо, ще у 1964 р. Суд СС ухвалив одне 3 найреволюційніших своїх рішень - Рішення у справі 6/64 Costa v. ENEL [19, p. 585]. Так, у цьому Рішенні Суд ЄС зазначив: «На відміну від міжнародних договорів, Договір про ЄЕС створив свій власний правопорядок, який після вступу в силу Договору став інтегральною частиною правових систем держав-членів...».

Таким чином, з аналізу зазначеного вище випливає, що практика Суду СС підкреслює унікальність природи інтеграційного права та його відокремленість від міжнародного та національного права. Суд $Є С$ постійно констатує, що установчі договори є конституційною хартією ЄС, заснованою на верховенстві права [18, p. 1339], або ще більше - внутрішньою конституцією Союзу [20, p. 741]. Так, на думку А. Лазовскі, перші натяки щодо руху у цьому напряму набули форми роком раніше в іншому основоположному рішенні у справі Van Gend en Loos, коли Суд ЄС проголосив доктрину прямої дії $[17$, р. 1].

Важливість обох рішень неможливо переоцінити. Разом із десятками судових рішень вони $\epsilon$ ресурсною точкою натхнення, що дає змогу науковцям із держав - членів ЄС та науковцям iз третіх держав досліджувати різні «виверти» права ЄС. Однак не слід забувати, що доктрина прямої дії залишається однією 3 найбільш суперечливих положень права $Є С$, що ставить перед Судом ЄС курс на зіткнення з кількома конституційними судами держав-членів [9, с. 36]. Зазначений вище автор констатує, що таке рішення Суду СС відносно доктрини прямої дії, по-перше, дало поштовх відомому дискурсу “kompetenz-kompetenz” i, що не дивно, спровокувало інтелектуальні зіткнення. Навіть більше, він вважає такі дії Суду ЄС юридичною авантюрою, що окупилася, проте мала ризики зірватися.

Аргументуючи свою позицію, А. Лазовскі наголошує на тому, що ані установчі договори, ані первинне законодавство ЄС не передбачають обов'язкового положення, яке проголошувало б верховенство права ЄС над національним правом держав-членів [9, с. 36].

Водночас автор слушно відмічає, що єдина спроба кодифікації верховенства права, що була зроблена в Договорі про запровадження Конституції для Європи, зазнала невдачі, оскільки цей Договір так і не набув чинності. Отже, за 60 років після заснуванню ЄЕС доктрина верховенства права, як і інші доктрини, що регулюють правозастосування ЄС на національному рівні, залишається правотворчістю судді [9, с. 37].

У теоретично-доктринальному аспекті помітно відрізняються також джерела міжнародного права та права ЄС. Так, джерелами міжнародного права $є$ міжнародний договір, міжнародний звичай, загальні принципи права, доктрина найбільш кваліфікованих фахівців, рішення міжнародних судових установ (ст. 38 Статуту Міжнародного Суду ООН) [13]. Як відомо, право ЄС через специфіку свого виникнення утворюється насамперед такими джерелами, як установчі договори ЄС. Крім того, джерелами права ЄС є такі акти, як рекомендації та висновки, які, на відміну від договорів міжнародного права, що визнані державами - членами міжнародного співтовариства за спеціальною процедурою (схваленням, ратифікацією, приєднанням, тощо), не мають обов'язкового юридичного характеру. Найважливішою рисою права ЄС є можливість видавати правові норми, які будуть мати обов'язкову силу для всіх держав - членів ЄС. До таких правових актів відносять регламент, директиву і рішення. Отже, всі акти $Є С$ умовно можна поділити на три великі групи. Перша - це класичні міжнародні договори, які підписуються кожним членом і ратифікуються окремо в державах - членах ЄС. Ця група фактично регулюється міжнародним публічним правом. Друга група - вторинне або похідне право (юридично обов'язкові приписи інститутів СС). Третя група - додаткове (третинне) право, яке включає в себе вузькоспеціалізовані міжнародно-правові договори в сфері охорони здоров'я, сільського господарства тощо.

Нарешті, структура системи міжнародного права, що складається із загальновизнаних принципів міжнародного права, договірних і звичаєво-правових норм, галузей і інститутів міжнародного права, що входять до них, має мало спільного з правом ЄС. Так, структура права ЄС $\epsilon$ менш великою за обсягом, ніж в міжнародному праві. Право ЄС поділяється на інституційне та матеріальне. Тобто, виходячи з наведених вище параметрально-змістовних ознак принципу верховенства права, що діє в міжнародному праві, він у такому профільному розумінні може бути застосованим тільки до першої групи джерел права ЄС. 
Водночас у результаті активних інтеграційних процесів, що були детерміновані та забезпечені діяльністю інституцій $€ С$, його право все більш стає наближеним до міжнародного права за своєю онтологічною суттю, оскільки все більш викристалізовуються загальні телеологічні домінанти в діяльності держав - членів СС, що все більш впливають на долю міжнародного співтовариства держав.

В спеціальній літературі зазначається, що з поглибленням європейської інтеграції більш складним та динамічним стає рівень взаємодії між нормами права ЄС та міжнародного права. Слід також зважати на те, що вплив міжнародного права на право ЄС постійно зростає. Це можна пояснити подальшим розширенням співпраці СС з іншими суб'єктами міжнародного права, завдяки чому збільшується обсяг міжнародних зобов'язань інтеграційного об'єднання. СС повинен забезпечити належне виконання своїх міжнародних зобов’язань шляхом імплементації міжнародно-правових актів як на міжнародному рівні, так і на рівні ЄС [4]. Тому не є випадковим виникнення, існування, функціонування та розвиток так званого «європейського міжнародного права», нормативною основою якого виступають правові норми права ЄС та інших організацій європейського регіону (РЄ, ОБСЄ, НАТО та інших), які забезпечують не тільки їх співробітництво на універсальному рівні міжнародних відносин через діяльність європейських наднаціональних інституцій та універсальних міжнародних організацій, але й могутні процеси взаємного впливу двох нормативних систем, включаючи й запозичення принципів права цих систем.

Аргументуючи такий підхід, вчений-міжнародник Ю.М. Колосов зазначає, що, по-перше, європейське право (право Європейського Союзу) можна вважати комплексною галуззю загального міжнародного права і частиною європейського міжнародного права; по-друге, «комплексною» галуззю воно є, оскільки складається з норм міжнародного (публічного) права, норм міжнародного приватного права і норм внутрішньодержавного права; по-третє, норми, що встановлюються інститутами (органами) ЄС, є нормами міжнародного (публічного) права, оскільки вони приймаються від імені держав, які добровільно делегували міжнародній організації частину своєї компетенції [7, с. 194-198].

Наведені положення у їх системно-комплексному розумінні свідчать про особливий змістовний характер принципу верховенства права в ЄС та його особливості щодо становлення, розвитку та застосування в діяльності його органів. Насамперед необхідно наголосити на тому, що в актах ЄС було надане визначення і розтлумачено зміст принципу верховенства права ЄС. Системний підхід до таких дій дає змогу зафіксувати особливості щодо змістовного наповнення та механізму реалізації цього принципу.

По-перше, він належить до функціональних принципів цього міждержавного об’єднання зі складною правовою природою. По-друге, його функціональність знаходить своє змістовне навантаження у відповідній організаційній парадигмі: а) принцип верховенства права ЄС означає пріоритет норм права ЄС над нормами національного законодавства держав-членів; б) правові норми національного законодавства держав-членів не повинні суперечити нормам права СС; в) зазначений принцип поширюється не тільки на установчі договори $€ C$, а й на низку його інших нормативних актів; г) гарантом дотримання цього принципу виступає Суд ЄС [10, с. 117-124].

Іншими словами, під час застосування принципу верховенства права $€ С$ акцент робиться на більш високу юридичну значимість права $Є С$ порівняно $з$ правовими актами його держав-членів. Отже, доктрину верховенства права ЄС прийнято виражати через позиції пріоритетності норм загальноєвропейського права над національним правом (держав-членів), несуперечності та відповідності положень національного права праву ЄС [10, с. 117-124; 15]. Таке відверто субординаційне розуміння верховенства права грунтується насамперед на концепції «наднаціональності».

На думку відомого юриста-міжнародника А.Я. Капустіна, під час побудови взаємозв' язків і взаємовідносин всередині міждержавної організації, членство в якій супроводжується обмеженням державами своїх суверенних прав в процесі передачі повноважень наднаціональній організації у встановлених сферах, саме такий принцип реалізується на практиці даного західноєвропейського інтеграційного об'єднання [5, с. 194-198]. Текстуально фундаментальний принцип верховенства права, поряд із такими основоположними принципами, як «свобода, демократія, повага прав людини і основних свобод», знайшов формальне закріплення у формі «принципу правової держави» ст. 6 (колишній статті F) Договору про Свропейський Союз [8] і був покладений в основу правопорядку СС. Принцип права ЄС, відповідно до якого закріплюється новий принцип - «принцип верховенства права ЄС», - $є$ основним елементом у співвідношенні норм права окремих держав - членів $\mathrm{CC}$ та "acquis communautaire $\mathrm{CC}$ ". 
Водночас концепція верховенства права в СС закріплена не лише у Преамбулі до Договору про утворення Європейського Союзу, але також у його ст. 2, відповідно до якої «Союз заснований на цінностях поваги до людської гідності, свободи, демократії, рівності, верховенства права та поваги до прав людини, включаючи права осіб, що належать до меншин» [8]. Вона також виступає основою для зовнішньої діяльності ЄС, а також закріплена у Преамбулі до Хартії основоположних прав Свропейського Союзу [16]. При цьому слід наголосити, що у французькій версії останньої вживається термін Etat de droit, тоді як в німецькій версії вживається термін Rechtsstaatlichkeit. Тут також немає змістовного визначення цього поняття. Концепція верховенства права вживалася в СС, охоплюючи багато значень, включаючи формальні поняття, такі як верховенство закону, а також і суттєві поняття, специфічні для права СС, такі як повага до основоположних прав і свобод, справедливе застосування права, ефективне користування правами Співтовариства, захист виправданих очікувань та навіть протидія корупції (у зовнішніх зв'язках).

Висновки. Отже, з урахуванням зазначеного вище можна зробити такі висновки. В установчих договорах ЄС, зокрема у Договорі про Свропейський Союз (2007р.), верховенство права постає не стільки як принцип права, скільки як філософсько-соціальна категорія - загальнолюдська цінність, яку мають поважати і якої мають дотримуватися. Це підтверджується системним тлумаченням відповідних нормативних положень під кутом аксіологічного розуміння їх потенціалу. Зокрема, в Договорі про ЄС ці цінності знайшли своє відображення таким чином: a) у Преамбулі зазначено, що держави-члени заснували Свропейський Союз, отримуючи натхнення від культурного, релігійного та гуманістичного спадку Європи, з якого розвинулися загальні цінності (непорушності та невідчужуваності прав особистості, свобода, демократія, рівність та верховенство права); б) ст. 2 містить перелік цінностей, на яких було засновано Союз, тут також підкреслюється, що ці цінності є спільними для всіх держав-членів, а також закріплено телеологічні домінанти, що демонструють практичне застосування наведених цінностей у суспільстві - панування плюралізму, недискримінації, толерантності, правосуддя, солідарності та рівності чоловіків та жінок.

Резюмуючи, можна зазначити, що саме у такий спосіб установчі договори СС нормативно закріпили загальновизнані принципи права, до яких належить і принцип верховенства права, як засадничі, основоположні щодо правової системи Європейського Союзу, відповідно, і правових систем його держав-членів.

\section{Список використаних джерел:}

1. Абашидзе А.Х., Алисиевич Е.С. Право Совета Европы. Конвенция о защите прав человека и основных свобод : учебное пособие. Москва : Междунар. отношения, 2007.

2. Баймуратов М.О. Міжнародне публічне право : підручник. Київ - Одеса : Фенікс, 2018.

3. Вершинина П.И. Место европейского права в системе международного права. URL: https://cyberleninka.ru/article/n/mesto-evropeyskogo-prava-v-sisteme-mezhdunarodnogo-prava.

4. Зітинюк Н.Ю. Співвідношення права Європейського Союзу з міжнародним правом. URL: http://dspace.onua.edu.ua/bitstream/handle/11300/6345/Zitunyk\%20Spivvidnoshennya. pdf? sequence $=1 \&$ isAllowed $=\mathrm{y}$

5. Капустин А.Я. Международные организации в глобализирующемся мире. Москва : Из-во РУДН, 2010.

6. Кашкин С.Ю., Ядрихинская О.А. История становления и развития науки Европейского права в России. URL: https://eulaw.ru/articles/history_of_eu_law/

7. Колосов Ю.М. О понятии европейского международного права. Российский ежсегодник международного права. 2006. Санкт-Петербург : Социально-коммерческая фирма «Россия-Нева», 2007.

8. Консолідовані версії Договору про Європейський Союз та Договору про функціонування Європейського Союзу з протоколами та деклараціями від 07.02.1992, 25.03.1957 \{Консолідовані версії станом на 30.03.2010\}. URL: https://zakon.rada.gov.ua/laws/show/994_b06.

9. Лазовські А. Верховенство права Європейського Союзу: юридична авантюра, що окупилася. Право України. 2019. №6 (57). С. 35-52.

10. Марченко М.Н. Верховенство права Европейского союза по отношению к национальному праву государств-членов. Журнал российского права. 2009. № 5. С. 117-124.

11. Недюха М.П. Системний аналіз історичних типів європейської ідеології. Ірпінь : Академія державної податкової служби, 2001. 404 с.

12. Про засади внутрішньої і зовнішньої політики: Закон України від 01.07.2010 № 2411-VI Редакція від 08.07.2018. URL: https://zakon.rada.gov.ua/rada/show/2411-17. 
13. Статут Міжнародного Суду OOH. URL: https://zakon.rada.gov. ua/laws/show/995_010).

14. Топорнин Б.Н. Европейское право : учебник. Москва, 2001.

15. Трстеньяк В. Принцип верховенства в праве Европейского союза и роль конституционных судов государств-членов. Международное правосудие. 2012. № 2. URL: http://center-bereg.ru/ o1361.html

16. Хартія основних прав Європейського Союзу : [пер. А. Пендак]. Ніцицький договір та розширення Європейського Союзу. Київ, 2001. 124 с.

17. Case 26/62, NV Algemene Transport- en Expeditie Onderneming van Gend \& Loos v Netherlands Inland Revenue Administration II European Court Reports. 1963.

18. Case 294/83, Parti ecologiste «Les Verts» v European Parliament II European Court Reports. 1986. P. 1339.

19. Case 6/64, Flamino Costa v. E.N.E.L. II European Court Reports. 1964. P. 585.

20. Opinion 1/76, Draft Agreement establishing a European laying-up fund for inland waterway vessels II European Court Reports. 1977. P. 741.

УДК 341.4

DOI https://doi.org/10.32844/2618-1258.2019.3-2.42

ЛАКІЙЧУК Я.О.

\section{МІЖНАРОДНИЙ ДОСВІД ЗДІЙСНЕННЯ ПРЕВЕНТИВНИХ ЗАХОДІВ ОРГАНАМИ ПОЛІЦЇ̈ ТА МОЖЛИВОСТІ ЙОГО ВИКОРИСТАННЯ В УКРАЇНІ}

У статті на основі аналізу наукової літератури досліджено досвід провідних країн Європи щодо здійснення превентивних заходів органами поліції та визначено можливості його використання в Україні. 3'ясовано, що в одних країнах робиться акцент на розширення повноважень поліцейських, в інших - на максимальну взаємодію із громадянами, залучення їх для допомоги у реалізації окремих поліцейських функцій, а в третіх - узагалі ще не вироблено ані поняття, ані сутності превенції як форми діяльності поліції. У зв'язку із цим не можна взяти за основу досвід якоїсь одної країни для імплементації в межах національних реалій.

Звернуто увагу на такий приклад взаємодії поліції та населення Великобританії щодо забезпечення публічного порядку та підвищення рівня безпеки громадян у районах їх проживання, як програма «Сусідське спостереження», основним призначенням якої постає спостереження за підозрілими людьми або потенційно небезпечними подіями, що відбуваються в районі проживання.

3'ясовано, що у Великобританії поряд із поліцією правоохоронного-превентивні функції здійснюють: по-перше, органи для яких функція охорони публічного порядку є другорядною (такі органи не є поліцейськими у власному значенні цього слова та складаються із цивільних службовців); по-друге, громадяни, що мають законодавчо встановлені повноваження у сфері охорони публічного порядку, зокрема, їм надано право припиняти злочини, а також доставляти правопорушників в органи поліції чи суду.

Зроблено висновок, що логічним є запозичення зарубіжного досвіду здійснення превентивних заходів у такому ракурсі: поглиблення «превентивних можливостей» поліцейських, розширення їхніх прав у сфері застосування превентивних заходів і полегшення механізму використання останніх; удосконалення нормативно-правової бази в частині детального регулювання процедур і порядку використання превентивних заходів, а також приведення іії у відповідність до міжнародних стандар-

(C) ЛАКІЙЧУК Я.О. - здобувач кафедри поліцейського права (Національна академія внутрішніх справ) 